Tanjungpura Law Journal, Vol. 4, Issue 1, January 2020: 1 - 21

ISSN Print: 2541-0482 | ISSN Online: 2541-0490

Open Access at: http://jurnal.untan.ac.id/index.php/tlj

Article Info

Submitted: 13 Mei 2019 | Reviewed: 20 Juli 2019 | Accepted: 22 September 2019

\title{
EKSISTENSI PRINSIP PENCEMAR MEMBAYAR DALAM SISTEM PENEGAKAN HUKUM AGRARIA
}

\author{
Fajar Sugianto', Sanggup Leonard Agustian², Nisa Permata Basti ${ }^{3}$
}

\begin{abstract}
Law Number 32 of 2009 concern about Environmental Protection and Management does not provide adequate regulation in providing sanctions against perpetrators of pollution, except only providing a legal basis for employers to provide compensation payments to victims of pollution. Therefore it is necessary to know about the position of the Polluter Pays Principle in the Environmental Legal System as Agrarian Reform. The principle of paying polluters who have the function of authorizing should not be formulated in the explanatory section of the article. If following the explanation of Law No. 23 of 1997 concerning Environmental Management, the purpose of the principle of polluter pays, even has many meanings such as paying to pollute or can be interpreted as a license to pollute. As a result of the study of international law, the principle of polluter pays has two meanings, namely as an economic instrument with the intention of charging fees to potential polluters and is also interpreted as a basic instrument to hold legal liability for incidents of environmental pollution.
\end{abstract}

Keywords: negligence; polluter pays principle; strict liability.

\begin{abstract}
Abstrak
Undang-Undang Nomor 32 Tahun 2009 tentang Perlindungan dan Pengelolaan Lingkungan Hidup tidak memberikan pengaturan memadai dalam memberikan sanksi terhadap pelaku pencemaran, kecuali hanya memberikan landasan hukum bagi pengusaha untuk memberikan pembayaran kompensasi kepada korban pencemaran. Oleh karena itu perlu mengetahui mengenai kedudukan Prinsip Pencemar Membayar (Polluter Pays Principle) dalam Sistem Hukum Lingkungan Sebagai Reformasi Agraria. Prinsip Pencemar Membayar yang memiliki fungsi mengesahkan seharusnya tidak dirumuskan dalam bagian penjelasan pasal. Jika mengikuti penjelasan Undang-undang No. 23 Tahun 1997 tentang Pengelolaan Lingkungan Hidup, maka maksud Prinsip Pencemar Membayar, bahkan memiliki banyak pemaknaan seperti membayar untuk mencemari (paying to pollute) atau dapat dimaknai sebagai license to pollute. Hasil telaah hukum internasional, prinsip pencemar membayar memiliki dua pemaknaan, yaitu sebagai instrumen ekonomi dengan maksud pembebanan biaya kepada pelaku pencemar yang potensial dan diartikan juga sebagai instrument dasar untuk menuntut pertanggungjawaban hukum atas terjadinya kasus pencemaran lingkungan.
\end{abstract}

Kata Kunci: kelalaian; prinsip pencemar membayar; tanggung jawab mutlak.

\footnotetext{
${ }_{1}^{1}$ Program Studi Hukum Bisnis, Universitas Agung Podomoro, APL Tower Lt. Podomoro City, Jl. Letjen S. Parman, Kav. 28, Jakarta Barat, 11470, Email: fajar.sugianto@podomorouniversity.ac.id.

${ }^{2}$ Program Studi Hukum Bisnis, Universitas Agung Podomoro, APL Tower Lt. Podomoro City, Jl. Letjen S.

Parman, Kav. 28, Jakarta Barat, 11470, Email: sanggup.leonardo@podomorouniversity.ac.id.

${ }^{3}$ Program Studi Hukum Bisnis, Universitas Agung Podomoro, APL Tower Lt. Podomoro City, Jl. Letjen S.

Parman, Kav. 28, Jakarta Barat, 11470
} 


\section{Pendahuluan}

Secara prinsip, barangsiapa yang menimbulkan kerugian diwajibkan untuk membayar kerugian tersebut. Hal ini senada dengan prinsip pencemar membayar (the Polluter Pays Principle): whoever is responsible for damage to the environment should bear the costs associated with it." ${ }^{\prime 4}$. Namun demikian, beberapa orang tidak setuju dengan dalil yang menyatakan bahwa orangorang yang menyebabkan kerusakan atau merugikan orang lain harus membayar untuk kerusakan yang ditimbulkan tersebut. Memaksa pencemar untuk membayar biaya kerusakan, secara efisiensi ekonomi dapat dikatakan adil. Kebijakan berdasarkan Prinsip Pencemar Membayar diterapkan untuk melindungi lingkungan tanpa mengorbankan efisiensi dari sistem ekonomi pasar bebas.

Penggunaan sumber daya alam yang cenderung bersifat eksploitasi dan tidak terkendali untuk kegiatan ekonomi, memunculkan ketidakadilan dalam pemanfaatannya, termasuk pada level tertentu dapat mengakibatkan bencana bagi kehidupan manusia. Ketidakadilan dalam pemanfaatan sumber daya alam ${ }^{5}$, dapat berupa

4 United Nations Environmental Programme (UNEP), 1992.

5 Schlosberg menyebutkan bahwa keadilan lingkungan adalah pendistribusian, but it is also about individual and community recognition, partipation, and functioning. Lihat: David Schlosberg, 2007, Defining Environmental penguasaan yang tidak memperhitungkan terjaganya lingkungan hidup untuk tetap menunjang kehidupan, termasuk terganggunya hak-hak masyarakat yang memiliki ketergantungan terhadap kelestarian fungsi-fungsi lingkungan hidup. Pemahaman tehadap kekayaan sumber daya alam sebagai 'milik bersama' dan dianggap sesuatu yang gratis akan tetap digunakan oleh pengguna sumber daya alam, jika pengaturan regulasi di bidang hukum lingkungan tidak dapat memberikan batasan-batasan yang jelas mengenai pola-pola pemanfaatan yang berkeadilan dan upaya perlindungannya. Tragedi terhadap sumber kekayaan bersama yang diakibatkan oleh kegiatan eksploitasi guna pemenuhan kepentingan ekonomi disebabkan karena tidak adanya mekanisme keseimbangan antara kegiatan ekonomi dan upaya perlindungan dan pelestariannya. 6 Hardin menyebutkan bahwa apa yang disebut the commons itu dipandang sebagai sesuatu hal yang 'gratis' sehingga segala kegiatan pemanfaatannya tidak disertai dengan

Justice, Theories, Movements, and Nature, Oxford University Press, New York, hlm. viii.

6 Marsudi Triatmodjo, 2001, Pengembangan Pengaturan Hukum dan Kelembagaan Pencemaran Laut oleh Sumber dari Darat di Kawasan Asia Tenggara, Disertasi, Universitas Gadjah Mada, Yogyakarta, hlm. 3. 
biaya pemulihan untuk menjaga kesinambungannya. ${ }^{7}$

Dalam proses produksi, produsen tidak memperhitungkan biaya pembuangan limbah dalam biaya produksi mereka, tetapi dibebankan kepada pengguna lingkungan laut lainnya. Dalam literatur ekonomi, biaya ekonomi yang dikeluarkan dari proses ekonomi pasar disebut sebagai external economy, atau externality. ${ }^{8}$ Keadaan ini karena adanya anggapan tradisional yang menyatakan bahwa air, misalnya, adalah barang bebas dan terbuka bagi siapa saja yang memanfaatkannya sehingga para produser berpikir bahwa keuntungan yang timbul atau biaya untuk mengendalikan pencemaran dibiarkan di luar proses produksi.

Kesadaran pelaku ekonomi untuk bertanggung jawab dan turut memikul beban atas potensi dampak negatif dari proses produksi yang ditimbulkan tidak menjadi dasar pertimbangan. Bahkan dalam politik pemanfaatan sumber daya alam, politik hukum Negara berorientasi pada eksploitasi (use oriented) sehingga berbagai kepentingan konservasi dan keberlanjutan sumber daya alam $^{9}$, karena semata-mata digunakan sebagai perangkat hukum (legal

\footnotetext{
7 Ibid.

8 Ibid., hlm. 371.

9 Dalam pengertian umum, sumber daya didefinisikan sebagai sesuatu yang dipandang memiliki nilai ekonomi. Dapat juga dikatakan sumber daya adalah komponen dari ekosistem yang menyediakan barang dan jasa yang bermanfaat bagi kebutuhan manusia.
}

instrument) untuk mendukung pertumbuhan ekonomi melalui peningkatan pendapatan dan devisa Negara. Sejak Pemerintah Indonesia menerima investasi modal asing melalui pemberlakuan Undang-Undang Nomor 1 Tahun 1961 tentang Penanaman Modal Asing dan dilanjutkan dengan undangan pemerintah dalam menarik investorinvestor asing mendorong pemerintah membentuk Undang-Undang Nomor 11 Tahun 1967 tentang Pertambangan. Merupakan apresiasi dari kebijakan Negara untuk memacu pertumbuhan ekonomi nasional, melalui eksploitasi sumber daya tambang yang dimiliki Indonesia, sehingga politik hukum yang melatarbelakangi pembentukan undang-undang tersebut adalah kemauan Negara mengeksploitasi sumber daya tambang untuk memacu pertumbuhan ekonomi. Anggapan ini dapat saja benar bila dihubungkan dengan Undang-Undang Nomor 32 Tahun 2009 tentang Perlindungan dan Pengelolaan Lingkungan Hidup (selanjutnya disebut "UUPPLH") dengan tidak memberikan pengaturan memadai dalam memberikan sanksi terhadap pelaku pencemaran, kecuali hanya memberikan landasan hukum bagi pengusaha untuk memberikan pembayaran kompensasi kepada korban pencemaran.

John Maddox memberikan argumentasi bahwa pencemaran akan 
dapat dipecahkan dengan menghitung ongkos-ongkos yang timbul (price) dan merupakan masalah dari factor ekonomi saja. Lebih lanjut diuraikan, 'we can reduce pollution if we are prepared to pay for it', sehingga dipahami seberapa besar kemampuan membayar, baik dengan program untuk menciptakan alat pencegah pencemaran (anti-pollution) maupun secara tidak langsung dengan membayar kerugian yang disebabkan oleh pencemaran. ${ }^{10}$

E.J. Mishan dalam the cost of economic growth pada tahun enam puluhan memperkenalkan Polluter Pays Principle (Prinsip Pencemar Membayar) yang menyebutkan bahwa pencemar semata-mata merupakan seseorang yang berbuat pencemaran yang seharusnya dapat dihindarinya. ${ }^{11}$ Mulai tahun 1972 Prinsip Pencemar Membayar dianut dan dikembangkan oleh Negara-negara Anggota Organisasi Kerjasama Ekonomi dan Pembangunan (Organization of Economic Co-operation and Development/OECD) ${ }^{12}$, yang pada intinya menyebutkan, bahwa pencemar harus menanggung beban atau biaya

10 Daud Silalahi, 1996, Hukum Lingkungan dalam Sistem Penegakan Hukum Lingkungan Indonesia, Alumni, Bandung, hlm. 12.

${ }^{11}$ Rangkuti, Sundari, 2000, Hukum Lingkungan dan Kebijaksanaan Lingkungan Nasional, edisi kedua, Airlangga University Press, Surabaya, hlm. 238.

12 Philip Sands, 2003, Principles of International Environmental Law, Second Edition, Cambridge University Press, United Kingdom, hlm. 281. pencegahan dan penanggulangan pencemaran yang ditimbulkan.

Pada perkembangan selanjutnya, Prinsip Pencemar Membayar tidak saja semata-mata dipahami sebagai bagian dari instrumen ekonomi, tetapi mulai bergeser pada bidang hukum. Dalam perspektif hukum positif yang dimiliki Indonesia, Prinsip Pencemar Membayar tidak memiliki pengaturan memadai, baik dalam tingkat dasar pengaturan hukum, pemaknaan dalam putusan-putusan pengadilan, termasuk kejelasan eksistensinya dalam praktekpraktek penyelesaian kasus-kasus pencemaran yang terjadi di Indonesia, sehingga perbandingan Prinsip Pencemar Membayar dalam sistem hukum lingkungan dapat menjadi pembaharuan hukum agraria, khususnya dalam reformasi sumber daya alam.

Berdasarkan uraian tersebut di atas, maka tulisan ini merumuskan permasalahan: Bagaimanakah kedudukan Prinsip Pencemar Membayar Dalam Sistem Hukum Lingkungan Sebagai Reformasi Agraria? 


\section{Metode}

Jenis penelitian yang digunakan dalam penelitian ini adalah penelitian yuridis normatif yaitu suatu penelitian yang dilakukan dengan mempelajari dan menelaah bahan hukum primer, sekunder, dan tersier yaitu inventarisasi peraturan mengacu kepada normanorma yang terdapat dalam peraturan perundang-undangan. Dalam hal ini yang berkaitan dengan UndangUndang Nomor 32 Tahun 2009 tentang Perlindungan dan Pengelolaan Lingkungan Hidup.

Pendekatan masalah yang digunakan dalam penelitian ini adalah pendekatan Undang-Undang (statute approach) dan pendekatan komparatif (comparative approach). "Pendekatan Undang-Undang (statute approach) dilakukan dengan menelaah semua Undang-Undang dan regulasi yang bersangkut paut dengan isu hukum yang sedang ditangani." ${ }^{13}$ Pendekatan perbandingan (comparative approach) adalah dengan memperbandingkan sistem hukum. "Studi perbandingan hukum merupakan kegiatan untuk membandingkan hukum suatu negara dengan hukum negara lain atau hukum dari suatu waktu tertentu dengan hukum dari waktu yang lain." 14

Sumber data yang digunakan dalam penelitian ini adalah data

13 Peter Mahmud Marzuki, 2010, Penelitian Hukum, Jakarta: Kencana, hlm. 93.

${ }^{14} \mathrm{Ibid}$, h. 173 sekunder berupa bahan hukum yang meliputi: bahan hukum primer, yakni bahan hukum berupa Undang-Undang dan peraturan lainnya yang berhubungan dengan masalah yang akan dibahas, dengan sumber-sumber yaitu Undang-Undang Nomor 32 Tahun 2009 tentang Perlindungan dan Pengelolaan Lingkungan Hidup; bahan hukum sekunder adalah bahan acuan lainnya yang berisikan informasi dan mendukung penjelasan-penjelasan mengenai bahan hukum primer, seperti literatur atau buku bacaan hukum, buku-buku para sarjana, hasil penelitian, jurnal, makalah, dan sebagainya yang berkaitan dengan penulisan ini; dan bahan hukum tersier adalah bahan yang memberikan petunjuk maupun penjelasan terhadap bahan-bahan primer dan sekunder seperti kamus bahasa maupun kamus hukum.

Metode pengumpulan data dengan cara studi kepustakaan (library research), yaitu mempelajari dan menganalisis secara sistematis, bukubuku, peraturan perundang-undangan dan bahan-bahan lain yang berhubungan dengan permasalahan yang akan menjadi pokok pembahasan dalam tulisan. 


\section{Analisis dan Pembahasan}

\section{A. Prinsip Hukum dan Konsep Pengaturan dalam Hukum Lingkungan}

Prinsip hukum adalah prinsip (asas) yang menjadi dasar bagi suatu sistem hukum ${ }^{15}$, yang berguna dalam pembuatan maupun dalam penerapan hukum. Mengenai apa yang dinamakan asas hukum atau prinsip hukum terdapat beberapa pendapat. Paul Scholten merumuskan asas hukum sebagai pikiran-pikiran dasar yang terdapat di dalam dan di belakang sistem hukum masing-masing dirumuskan dalam peraturan perundang-undangan dan putusanputusan hakim (yurisprudensi), yang berkenaan dengan ketentuanketentuan dan keputusan-keputusan individual dapat dipandang sebagai penjabarannya. ${ }^{16}$

Dalam definisi tersebut tampak dengan jelas peranan asas hukum sebagai meta-kaidah berkenaan dengan kaidah hukum dalam bentuk kaidah perilaku. Dalam definisi Scholten di atas disimpulkan lebih lanjut bahwa asas-asas hukum

15 Black mendefinisikan principle sebagai a fundamental truth or doctrine, as of law; a comprehensive rule or doctrine which furnishes a basis or origin for others; a settled rule of action, procedure or legal determination, lihat: Henry Campbell Black, 1990, Black's Law Dictionary, $6^{\text {th }}$ ed., West Publishing Co., St. Paul, hlm. 1193.

${ }^{16}$ Paul Scholten dalam J.J.H. Bruggink, 1999, Refleksi tentang Hukum, alih Bahasa Arief Sidharta, Cetakan ke-2, Citra Aditya Bakti, Bandung, hlm. 119-120. mewujudkan sejenis sistem sendiri, yang sebagian termasuk ke dalam sistem hukum, tetapi sebagian lainnya tetap berada di luar sistem hukum. Menurut Paul Scholten, asas-asas hukum itu berada di dalam sistem hukum maupun di belakangnya. Dalam hal ini, pikiran Scholten terarah pada sistem hukum positif. Peranan ganda dari asas hukum berkenaan dengan sistem hukum positif itu berkenaan dengan sifat asas hukum sebagai kaidah penilaian. Asas hukum mengungkapkan nilai, yang harus kita perjuangkan untuk mewujudkannya, tetapi hanya sebagian saja dapat direalisasikan dalam hukum positif. Sejauh nilai suatu asas hukum diwujudkan dalam kaidah hukum dalam sistem hukum positif, maka asas hukum itu berada dalam sistem tersebut.

Karl Larenz menyebutkan bahwa asas hukum adalah gagasan yang membimbing dalam pengaturan hukum (yang mungkin ada atau sudah ada), yang dirinya sendiri bukan merupakan aturan yang dapat diterapkan, tetapi yang dapat diubah menjadi semikian. ${ }^{17}$ Robert Alexy membedakan antara asas hukum dan peraturan hukum. Menurut pendapatnya, asas hukum adalah 'optimierungsgebote' yang berarti aturan yang mengharuskan bahwa sesuatu berdasarkan kemungkinankemungkinan yuridis dan faktual

\footnotetext{
17 Ibid., hlm. 121.
} 
seoptimal mungkin direalisasikan. Sebaliknya, aturan hukum adalah yang selalu dapat atau tidak dapat dipatuhi. ${ }^{18}$ Ron Jue membatasi pengertian asas hukum sebagai nilai-nilai yang membatasi kaidah-kaidah hukum disebut asas-asas hukum. Asas hukum itu menjelaskan dan melegitimasi kaidah hukum, diatasnya bertumpu muatan ideologis dari tatanan hukum. Karena itu, kaidah-kaidah hukum dapat dipandang sebagai operasionalisasi atau pengolahan lebih jauh dari asasasas hukum. ${ }^{19}$

Bellefroid menyebutkan bahwa asas hukum umum adalah norma dasar yang dijabarkan dari hukum positif dan yang oleh ilmu hukum tidak dianggap berasal dari aturan-aturan yang lebih umum. Asas hukum itu merupakan pengendapan hukum positif dalam suatu masyarakat. ${ }^{20}$

Asas hukum mempunyai dua fungsi, yaitu fungsinya dalam hukum dan ilmu hukum. Fungsi asas hukum dalam hukum berdasarkan eksistensinya pada rumusan oleh pembentuk undang-undang dan hakim (ini merupakan fungsi yang bersifat mengesahkan) serta mempunyai pengaruh yang normatif dan mengikat para pihak. Fungsi asas hukum dalam ilmu hukum hanya bersifat mengatur

\footnotetext{
18 Ibid.

19 Ibid.

${ }^{20}$ Bellefroid dalam Sudikno Mertokusumo, 2005, Mengenal Hukum, Cet. Ke-2, Liberty, Yogyakarta, hlm. 34.
}

dan eksplikatif (menjelaskan). Tujuannya adalah memberi ikhtisar, tidak normatif sifatnya dan tidak termasuk hukum positif. ${ }^{21}$

Upaya pelestarian terhadap lingkungan hidup dengan mengedepankan Prinsip Pencemar Membayar dalam perumusan kebijakan pemerintah juga merupakan salah satu bentuk dari konsep Pembangunan Berkelanjutan sebagaimana tercermin dalam ketentuan Pasal 33 ayat (4) Undang-Undang Dasar 1945 Amandemen Ke-empat (selanjutnya disebut "UUD 1945") yang mengatur sebagai berikut:

"Perekonomian nasional diselenggarakan berdasar atas demokrasi ekonomi dengan prinsip kebersamaan, efisiensi berkeadilan, berkelanjutan, berwawasan lingkungan, kemandirian, serta dengan menjaga keseimbangan, kemajuan dan kesatuan ekonomi nasional."

Pembangunan berkelanjutan dapat diturunkan menjadi beberapa elemen inti, yaitu prinsip integrasi (integration principle), prinsip pemanfataan berkelanjutan (sustainable use), prinsip keadilan intra generasi (intragenerational equity), dan prinsip keadilan antar generasi (intergenerational equity).

Elemen-elemen ini juga dikemukakan oleh Philippe Sands, yang menyatakan bahwa elemen

21 Ibid., hlm. 36. 
hukum dari pembangunan berkelanjutan terdiri atas:

a. Keadilan antar generasi (intergenerational equity), yang dapat dilihat dari kebutuhan untuk melindungi Sumber Daya Alam (selanjutnya disebut "SDA") bagi keuntungan generasi yang akan datang;

b. Pemanfaatan secara berkelanjutan (the principle of sustainable use), yang direflesikan dalam eksploitasi SDA secara berkelanjutan, hati-hati (prudent), rasional (rational), bijaksana (wise), dan layak (appropriate);

c. Keadilan intra generasi, yang ditunjukkan melalui pemanfaatan SDA secara berkeadilan (equitable use of natural resources), dimana pemanfaatan SDA oleh satu negara tetap harus memperhatikan kebutuhan dari negara lain; dan

d. Prinsip integrasi (integration principle), yang meminta adanya jaminan bahwa pertimbangan lingkungan akan diintegrasikan ke dalam rencana, kebijakan, serta program terkait ekonomi terkait ekonomi dan pembangunan, serta bahwa pemenuhan kebutuhan pembangunan harus memperhatikan tujuan perlindungan lingkungan. ${ }^{22}$

22 Andry G. Wibisana, 2017, "Keadilan dalam Satu (Intra) Generasi: Sebuah Pengantar Berdasarkan Taksonomi Keadilan Lingkungan", Jurnal Mimbar Hukum Vol. 29, Nomor 2, Juni
Prinsip Pencemar Membayar memberi arah dalam pengaturan hukum lingkungan terkait adanya pencemaran lingkungan yang merusak kelestarian lingkungan dan bertentangan dengan konsep pembangunan berkelanjutan. Asas ini menunjuk pada suatu kewajiban atau pembebanan kepada pencemar untuk membayar kerugian yang dialami korban. Permasalahan yang muncul kemudian menyangkut konsep yang dimaknai dalam pengaturan regulasi hukum lingkungan di Indonesia. Pada rumusan penjelasan dalam Pasal 34 Undang-Undang Nomor 23 Tahun 1997 tentang Pengelolaan Lingkungan Hidup (selanjutnya disebut UUPLH), misalnya menyisakan masalah tersendiri jika dilihat dari fungsi asas hukum. Asas Pencemar Membayar yang memiliki fungsi mengesahkan, seharusnya tidak dirumuskan dalam bagian penjelasan pasal. Penempatan rumusan 'asas pencemar membayar' (diartikan sebagai Polluter Pays Principle) dalam penjelasan, berpotensi menimbulkan norma baru 23 , dan bahkan membingungkan, antara hukum yang dianut menggunakan ketentuan dalam Pasal 34 ayat (1) UUPLH atau

2017, hlm. 292-307, dalam https://jurnal.ugm.ac.id/jmh/article/view/19143/17 301, diakses pada 02 September 2019.

23 Sebagai bukti penggunaan asas ini pada tingkat praktek adalah dibebaskannya tersangka pencemaran lingkungan (pembuangan slude oil/lantung) oleh Polda Kaltim Tahun 2004 dengan alasan pencemar telah melakukan pembayaran (pencemar membayar). 
mengikuti isi penjelasan Pasal 34 ayat (1) UUPLH tersebut. Jika mengikuti penjelasan, maka maksud dari Prinsip Pencemar Membayar, bahkan memiliki banyak pemaknaan seperti membayar untuk mencemari (paying to pollute) atau dapat dimaknai sebagai license to pollute.

\section{B. Pengaturan Prinsip Pencemar Membayar}

Pertumbuhan tata pengaturan secara hukum lingkungan modern diawali setelah lahirnya Deklarasi tentang lingkungan hidup yang diselenggarakan pada tahun 1972 sebagai hasil dari Konferensi PBB tentang lingkungan hidup manusia di Stockholm yang merupakan wujud nyata dari pembangunan kesadaran umat manusia terhadap masalah lingkungan hidup. Deklarasi tentang lingkungan hidup tersebut berisi 26 (dua puluh enam) asas pelestarian dan pengembangan lingkungan hidup yang dilandasi oleh 7 (tujuh) pokok pertimbangannya.

Deklarasi Stockholm yang menghasilkan asas-asas pelestarian dan pengembangan lingkungan hidup bukan merupakan suatu asas-asas yang harus ada dalam hukum lingkungan negara Indonesia. Untuk dapat mengembangkannya menjadi asas-asas hukum lingkungan nasional maka pengaturan kebijakan dalam asas-asas pelestarian dan pengembangan lingkungan hidup tersebut perlu diolah dahulu untuk kemudian dapat dituangkan ke dalam asas hukum lingkungan Indonesia. Oleh karena itu, Deklarasi Stockholm hanya menjadi referensi bagi pengembangan hukum lingkungan dan tata pengaturannya.

Munadjat Danusaputro, menyatakan bahwa dalam 26 (dua puluh enam) asas yang dideklarasikan dalam Deklarasi Stockholm tersebut, hanya ada satu asas yang secara khusus menyebut dan merujuk pada arah pengembangan hukum lingkungan, Asas tersebut adalah asas ke-22. Kemudian asas tersebut didukung oleh asas ke-17 dan asas-21 dalam pelaksanaanya secara nasional maupun internasional.

Asas 22 Deklarasi Stockholm berbunyi: "state shall co-operate to develop further the international law regarding liability and compensation for the victims of pollution and other environmental damage caused by activities within the juruisdiction or control of such states to areas beyond their jurisdiction", (Negara-negara akan bekerjasama dalam mengembangkan lebih lanjut hukum internasional mengenai tanggung jawab hukum (tanggung gugat) dan ganti rugi terhadap para korban pencemaran atau kerusakan lingkungan akibat kegiatan dalam wilayah kewenangan atau pengawasan negara yang 
bersangkutan kepada wilayah di luar kewenangnnya).

Dalam rangka hari lingkungan hidup, pada tanggal 5 Juni 2006, Indonesian Center for Environmental Law (ICEL) menuntut adanya perbaikan pengelolaan lingkungan dan sumber daya alam dengan pendekatan yang lebih komprehensif dengan mendasarkan pada penerapan asasasas umum kebijaksanaan lingkungan yakni Prinsip Pencemar Membayar (Polluter Pays Principle) melalui pengembangan kebijaksanaan pemberian insentif pajak pemasukan alat pengelolah limbah bagi industri yang taat lingkungan,insentif lain bagi pengembangan industri yang melakukan daur ulang (reused, recycling).

Hukum internasional telah lama mengatur soal kewajiban bagi pelaku pencemaran lingkungan yang melewati batas suatu negara atau satu pihak ke pihak lainnya. Dikenal dengan istilah Transfrontier Pollution (TFP). Sejak awal dekade 1970-an, permasalahan ini telah sering terjadi sehingga menimbulkan pemikiran tentang perlunya kesepakatan yang mengatur sekaligus mengatasi masalah tersebut. Contoh perjanjian yang telah disepakati yang mengatur masalah TFP ini adalah Perjanjian Brussel tentang intervensi di lautan terbuka terkait korban pencemaran minyak (Brussels Convention Relating to Intervention on
The High Seas In Cases of Oil Pollution Casualties) serta perjanjian pertanggungan sipil untuk kerusakan karena pencemaran minyak (Convention on Civil liability for Oil Pollution Damage).

Dua perjanjian itu dilatarbelakangi dengan terjadinya peristiwa kandasnya kapal tanker minyak Torrey Canyon di lepas pantai Inggris pada tahun 1967. Kedua perjanjian di atas menjadi pokok yang penting dalam pengaturan lingkungan hidup yang bersifat public goods atau barang umum seperti udara, air, dan lautan.

\section{Prinsip Pencemar Membayar} merupakan salah satu prinsip yang penting dalam pengelolaan lingkungan, selain prinsip the sustainable development, the prevention principle; the precautionary principle; and the proximity principle. ${ }^{24}$ Pengaturan Prinsip Pencemar Membayar untuk pertama kali dirumuskan oleh Organization for Economic Cooperation and Development (selanjutnya disebut OECD), dan dalam ketentuan-ketentuan hukum European Communities (EC) tahun 1972. Selanjutnya tahun 1973, merupakan penerapan pertama kali kedalam masalah-masaslah lingkungan hidup. ${ }^{25}$

\footnotetext{
${ }^{24}$ Michael Faure and Goran Skogh, 200 3, The Economic Analysis of Environmental Policy and Law, an Introduction, Edward Elgar Publishing Inc., Massachusett, USA, hlm. 5.

25 Philip Sands QC, Op.Cit., hlm. 281-283.
} 
Keberadaan Prinsip Pencemar Membayar dapat ditemukan dalam berbagai dokumen hukum (terutama soft law dalam kategori soft principles) ${ }^{26}$, berkembang dalam penggunaannya dan diatur dalam dokumen-dokumen hukum internasional, di antaranya, the 1980 Athens Protocol for the Protection of Mediteranian Sea against Pollution from Land-based Sources and activities 27 , the 1992 Helsinki Convention on the Transboundary Effects of Industrial Accidents ${ }^{28}$, the 1993 Lugano Convention on Civil Liability for Damage resulting from Activities Dangerous to the Environment ${ }^{29}$, the 1992 Helsinki Convention on the Protection and Use of Transboundary Watercourses and International Lakes ${ }^{30}$, the 1996 London Protocol to the Convention on the Prevention of Marine Pollution by Dumping of Wastes and Other Matter. ${ }^{31}$

26 Soft Law meliputi soft principles (seperti: Declaration) dan kategori sebagai normative recommendations. Normative recommendation pada umumnya berisi norma-norma tentang standar-standar yang dapat dijadikan pedoman mengenai apa yang ditetapkan dan bagaimana melakukannya, lihat: Marsudi Triatmodjo, 1998, Peran dan Fungsi Soft Law dalam Perkembangan Hukum Internasional tentang Hak Asasi Manusia dan Lingkungan Hidup, Mimbar Hukum, Nomor 31/VIII/1998, Fakultas Hukum UGM, Yogyakarta, hlm. 43.

27 United Nations Environmental Programme (UNEP), 1992.

28 United Nations Economic Commission for Europe (UNECE), 1992.

29 European Communities Civil and Comercial Matters, 1993.

30 United Nations Economic Commission for Europe (UNECE), 1992.

31 London Protocol, (International Maritime Organization), 1972/1996.
Polluter Pays Principle juga ditemukan dalam rumusan prinsip ke16 the Rio Declaration on Environment and Development yang menyebutkan bahwa:

"National authorities should endeavor to promote the internalization of environmental costs and the use of economic instruments, taking into account the approach that the polluter should, in principle, bear the costs of pollution, with due regard to the public interests and, without distorting international trade and investment. ${ }^{\text {B2 }}$

Hal ini juga ditegaskan oleh Sands dengan mengemukakan bahwa 'the practical implications of the polluter pays principle are its aloocation of economic obligations in relation to environmentally damaging activities, particularly in relation to liability, the use of economic instrument, and the application of rules relating to competition and subsidy. ${ }^{33}$ Meskipun demikian, prinsip ini telah menjadi solusi bagi beberapa Negara dalam membangun sistem hukum nasionalnya terutama dalam mengatur kasus-kasus pencemaran lingkungan.

OECD merumuskan 'apa yang harus dibayar' terkait dengan penerapan Prinsip Pencemar Membayar. Salah satu rumusannya, bahwa pencemar selayaknya dibebani kewajiban membayar akibat pencemaran yang ditimbulkan. Namun

32 The Rio Declaration, UN, 1992.

33 Philip Sands, Op.Cit., hlm. 280. 
demikian, muncul penentangan dengan alasan:

a. Pemulihan lingkungan tidak ada artinya dalam hal terjadinya kerusakan hebat yang dampaknya tidak dapat diselesaikan dengan ganti kerugian murni;

b. Pemulihan kerusakan mengandung banyak kesulitan misalnya dampak jangka panjang dan penemuan dampak tidak langsung;

c. Perkiraan biaya kerusakan terhadap biaya pemulihan perbaikan kerusakan seringkali siasia dari segi ekonomik. ${ }^{34}$

Selanjutnya OECD merumuskan lebih lanjut, penerapan prinsip pencemar membayar dilakukan dengan membebani biaya kegiatan yang perlu untuk mencegah pencemaran, dalam bentuk pungutan insentif yang sama dengan biaya pembersihan limbah, atau hanya menetapkan kriteria yang mengharuskan mengambil upaya pencegahan ${ }^{35}$ Menurut OECD, upaya pengendalian pencemaran melibatkan biaya-biaya alternatif penerapan kebijakan anti pencemaran, biaya pengukuran dan pemantauan pengelolaan, biaya riset, pengembangan terknologi unit-unit pengelolaan pencemaran, dan perawatan instalasi unit-unit pengelolaan limbah. Prinsip-prinsip yang diterapkan oleh OECD tercakup

${ }^{34}$ Sundari Rangkuti, Op.Cit., hlm. 253.

35 lbid., hlm. 253. dalam tujuh kebijaksanaan yang diambil, yakni: pengendalian langsung, perpajakan, pembayaran, subsidi, macam-macam kebijakan yang bersifat insentif seperti keuntungan pajak, fasilitas kredit, dan amortisasi atau pelunasan hutang yang mempercepat (accelerated amortization), pelelangan hak-hak pencemaran (the action of pollution right), pungutan-pungutan (charge).

Penerapan Prinsip Pencemar Membayar dalam kaitannya dengan instrumen ekonomi juga memiliki kelemahan, karena pembayaran yang digantungkan kepada jumlah pollutan yang dikeluarkan masih harus melihat "the lifetime of production project" sehingga pengenaan pajak lingkungan tidak akan efektif dan menimbulkan efek negatif bagi kesejahteraan sosial. ${ }^{36}$

Rumusan Prinsip Pencemar Membayar yang menggabungkan antara instrumen ekonomi dan hukum dapat ditelusuri dari paham yang diajukan oleh Seerden, sebagai berikut: "Under the Polluter Pays Principle, the polluter basically must avoid any negative environmental impact. He must at least repair all detrimental consequenses. This principle not only concerns the allocation of cost of avoidance, removal and compensation of environmental impact. It also

36 Irina Glazyrina, Vesiliy Glazyrin, Sergey Vinnichenko, 2005, The Polluter Pays Principle and Potential Conflicts in Society, dalam www.sciencedirect.com/polluter pays principle analysis.pdf, diakses tanggal 1 November 2016. 
justifies measures of direct conduct (orders, prohibitions), incentive charge, and leads to claims which compel those responsible to do something, or to claim concerning liability under civil law. Therefore, this principle serves as substantial principle in determining responsible for environmental impact, danger and risk. ${ }^{.37}$

Meskipun pandangan di atas masih memiliki pertalian dengan aspek pengalokasian biaya dalam penanggulangan pencemaran, tetapi juga memasuki ranah pertanggungjawaban hukum. Dalam banyak kasus pencemaran lingkungan, pertanggungjawaban hukum termasuk tindakan untuk menghilangkan dampak negatif menjadi tuntutan dalam proses menyeimbangkan antara kepentingan kalangan industri dan kepentingan masyarakat, termasuk kebutuhan menjaga pelestarian kemampuan lingkungan hidup yang serasi dan seimbang. ${ }^{38}$

Dari uraian tersebut di atas, nampak bahwa Prinsip Pencemar

37 Seerden, Rene J.G.H., Michiel A, Heldeweg and Kurt R. Deketelaere (eds), 2002, Public Environmental Law in the European Union and The United States, A Comparative Analysis, The Hague, Published by Kluwer Law International, Netherlands, hlm. 210-211.

38 Istilah "pelestarian kemampuan lingkungan hidup yang serasi dan seimbang" membawah kepda keserasian antara "pembangunan" dan "lingkungan", sehingga kedua pengertian itu, yaitu "pembangunan" dan "lingkungan" tidak dipertentangkan satu dengan yang lain. Adapun "pelestarian lingkungan" yang bermakna melestarikan lingkungan itu an sich digunakan dalam rangka kawasan pelestarian alam dan kawasan suaka alam. Lihat Koesnadi Hardjasoemantri, 2006, Hukum Tata Lingkungan, ed. 8, cet. ke-19, Gadjah Mada University Press, Yogyakarta, hlm. 98.
Membayar memiliki dua pemaknaan, yaitu sebagai instrumen ekonomi dengan maksud pembebanan biaya kepada pelaku pencemar yang potensial untuk membayar kerugian atas kerugian yang ditimbulkan dan diartikan juga sebagai instrument dasar untuk menuntut pertanggungjawaban hukum atas terjadinya kasus pencemaran lingkungan.

OECD memberikan definisi: "the polluter should bear the expenses of carrying out measures decided by publik authorities to ensure that the environment is in "acceptable state" or in other words the cost of these measures should be reflected in the cost of goods and services which cause pollution in production and or in consumption."

Studi yang dilakukan OECD dalam menghadapi masalah pengendalian pencemaran, menyimpulkan terdapat dua aliran utama, yaitu:

a. Golongan yang menginginkan pengendalian langsung dengan satu-satunya strategi adalah diberlakukannya peraturan terhadap para pencemar, terutama mengenai standar emisi; dan

b. Golongan yang lebih menyukai pendekatan ekonomi. Golongan ini mengemukakan, berbagai sumber daya alam terbuang sia-sia karena dianggap gratis atau kurang dipertimbangkan. Mereka 
menganggap perlu ditetapkannya "harga wajar" yang meliputi pula pungutan pencemaran.

Dari sudut pandang ekonomi, pungutan merupakan instrumen pengendalian pencemaran yang paling efektif. Karena pungutan merupakan insentif permanen guna mengurangi pencemaran dan menekan biaya penanggulangan. Namun anggapan tersebut dibantah, yang menganggap biaya pungutan sama dengan biaya pembelian hak untuk mencemari. Argumen tersebut disanggah dengan adanya kenyataan bahwa pungutan pencemaran yang diperhitungkan secara tepat dapat mendorong pencemar untuk mengurangi emisi karena dengan jalan tersebut penanggulangan limbah akan lebih murah daripada mencemarkan dan kemudian harus membayar tuntutan ganti rugi akibat pencemaran.

Prinsip Pencemar Membayar merupakan penjabaran dari teori-teori ekonomi tentang lingkungan (environmental economics) dimana pencemaran/kerusakan lingkungan dianggap sebagai sebuah bentuk kegagalan pasar (market failure) yang menimbulkan inefisiensi. Pencemaran lingkungan menunjukkan private costs \# social costs, yaitu bahwa biaya-biaya lingkungan tidak dipertimbangkan dalam pengambilan keputusan. Hal ini disebut sebagai eksternalitas.
Instrumen untuk menerapkan Prinsip Pencemar Membayar, antara lain melalui sistem pertanggung jawaban: negligence versus strict liability bertujuan agar ganti rugi yang diberikan harus mampu melindungi kepentingan para korban dan memberikan insentif kepada calon pencemar untuk bertindak secara hatihati

\section{a. Negligence}

Pencemar bertanggungjawab jika ia tidak optimal mengambil langkah-langkah pencegahan (optimal care), sehingga pencemar yang rasional akan mengambil langkah optimal sepanjang biaya biaya ganti rugi lebih besar dari pada biaya pencegahan optimal

b. Strict liability

- Pencemar bertanggungjawab manakala timbul kerugian (tanpa melihat apakah ia telah mengambil langkah pencegahan secara optimal atau tidak).

- Pencemar akan melakukan pencegahan sebanyak mungkin karena kerugian akan semakin berkurang ketika pencegahan semakin banyak dilakukan.

Kebijakan berdasarkan Prinsip

$\begin{array}{lcc}\text { Pencemar } & \text { Membayar } & \text { harus } \\ \text { memudahkan } & \text { masyarakat } & \text { untuk } \\ \text { melindungi } & \text { lingkungan } & \text { tanpa } \\ \text { mengorbankan } & \text { efisiensi dari } & \text { sistem } \\ \text { ekonomi pasar bebas. Pencemar disini }\end{array}$


dapat berupa perorangan, perusahan, maupun organisasi.

Terdapat 3 (tiga) pokok pikiran yang terkandung dalam Prinsip Pencemar Membayar. Pertama, penegasan pada tanggung jawab bersama dan sama tiap-tiap negara untuk melindungi lingkungan hidup baik pada pada tingkat nasional, regional, maupun global. Kedua, perhatian untuk melakukan usaha mencegah, mengurangi dan mengontrol ancaman terhadap lingkungan hidup didasarkan pada perbedaan keadaan masingmasing negara, khususnya dalam hal kontribusi tiap-tiap negara tersebut pada terjadinya pertambahan intensitas ancaman terhadap lingkungan hidup dan atau kerusakan lingkungan hidup yang terjadi. Ketiga, bahwa prinsip kebijakan lingkungan yang mengharuskan biaya pencemaran harus ditanggung oleh mereka yang menyebabkan itu.

\section{Polluters Pays Principle dalam Perkembangan Hukum \\ Lingkungan di Indonesia}

Dalam perkembangan hukum di Indonesia, Prinsip Pencemar Membayar (Polluter Pays Principle) tidak hanya melingkupi instrumen ekonomi, melainkan telah masuk pada instrumen hukum. Dalam hukum positif yang mengatur perlindungan dan pengelolaan lingkungan hidup yang berlaku saat ini yaitu UUPPLH, Prinsip Pencemar Membayar telah diadopsi kedalam Undang-undang tersebut. Pasal 2 UUPPLH menyebutkan sebagai berikut:

"Perlindungan dan pengelolaan lingkungan hidup dilaksanakan berdasarkan 14 asas, yaitu:

1) Tanggung jawab Negara;

2) Kelestarian dan keberlanjutan;

3) Keserasian dan keseimbangan;

4) Keterpaduan;

5) Manfaat;

6) Kehati-hatian;

7) Keadilan;

8) Ekoregion;

9) Kenekaragaman hayati;

10) Pencemar membayar;

11) Partisipatif;

12) Kearifan lokal;

13) Tata kelola pemerintahan yang baik; dan

14) Otonomi daerah."

Dalam penjelasan Undangundang mengenai Prinsip Pencemar Membayar yang tercantum pada Pasal 2 huruf (J) UUPPLH, yang dimaksud dengan Asas Pencemar Membayar (Polluter Pays Principle) adalah "bahwa setiap penanggung jawab yang usaha dan/ atau kegiatannya menimbulkan pencemaran dan/ atau kerusakan lingkungan hidup wajib menanggung biaya pemulihan lingkungan".

Pasal 42 ayat (1) UUPPLH "Dalam rangka melestarikan fungsi lingkungan hidup, pemerintah dan pemerintah daerah wajib mengembangkan dan menerapkan instrumen ekonomi lingkungan hidup" yang kemudian diterangkan pada Pasal 42 ayat (2) UUPPLH "Instrumen ekonomi lingkungan hidup 
sebagaimana dimaksud pada ayat (1) meliputi:

a. perencanaan pembangunan dan kegiatan ekonomi;

b. pendanaan lingkungan hidup; dan

c. insentif dan/atau disinsentif.

Kemudian lebih lanjut diterangkan pada Pasal 43 UUPPLH bahwa instrumen perencanaan pembangunan dan kegiatan ekonomi salah satunya meliputi internalisasi biaya lingkungan hidup yaitu memasukkan biaya pencemaran dan/atau kerusakan lingkungan hidup dalam perhitungan biaya produksi atau biaya suatu usaha dan/atau kegiatan, serta yang dimaksud dengan insentif dan/atau disinsentif yaitu pemberian insentif ekonomi pada pemilik kegiatan yang taat kepada persyaratan lingkungan dapat merangsang penaatan, terutama bagi perusahaan milik negara yang penerapannya antara lain melalui penerapan pajak, retribusi, dan subsidi lingkungan hidup. Sebaliknya kegiatan/atau usaha yang tidak taat akan dikenakan disinsentif berupa pungutan. Hal ini muncul karena selama ini lingkungan tidak diberi nilai/harga maka dalam perkembanganya manusia atau badan hukum (terutama yang berorientasi pada profit) banyak menggunakan sumber daya alam secara berlebihan dan cenderung membabat habis tanpa berpikir akibat bagi generasi yang akan datang. Tentu yang tersisa hanya derita dan bencana yang harus ditanggung baik harga, benda dan nyawa. Untuk itu, usaha memberi suatu biaya lingkungan yang ada pada Pasal 42 jo. Pasal 43 UUPPLH ini menjadi langkah awal untuk mereformasi dari UndangUndang sebelumnya yakni UndangUndang Nomor 23 Tahun 1997 tentang Pengelolaan Lingkungan Hidup (“UUPLH”). Gagasan yang terkandung dalam Pasal tersebut, sebagai pengejawantahan dari prinsip biaya lingkungan dan sosial yang terintegrasikan ke dalam proses pengambilan keputusan yang berkiatan dengan penggunaan sumber daya alam, sehingga pada akhirnya terjadi internalisasi "eksertenalitas" dalam arti ekserternalitas harus menjadi bagian dari pengambilan keputusan. Dengan memanfaatkan instrumen yang ada di Undang-Undang tersebut berupa pengaturan (larangan dan sanksi), charge, fees, leasing, perizinan, mekanisme property right dan lain-lain.

Pasal 87 ayat (1) UUPPLH, juga menyebutkan bahwa "Setiap penanggung jawab usaha dan atau / kegiatan yang melakukan perbuatan melanggar hukum berupa pencemaran dan atau / perusakan lingkungan hidup wajib membayar ganti rugi dan atau / melakukan tindakan tertentu". Dalam penjelasan Pasal 87 ayat (1) UUPPLH tersebut diterangkan: "Ketentuan dalam ayat ini merupakan realisasi asas yang ada dalam hukum lingkungan hidup 
yang disebut Asas Pencemar Membayar (Polluter Pays Principle). Selain diharuskan membayar ganti rugi, pencemar dan/atau perusak lingkungan hidup dapat pula dibebani oleh hakim untuk melakukan tindakan hukum tertentu, misalnya perintah untuk:

a. Memasang atau memperbaiki unit pengolahan limbah sehingga limbah sesuai dengan baku mutu lingkungan hidup yang ditentukan;

b. Memulihkan fungsi lingkungan hidup; dan/atau

c. Menghilangkan atau memusnahkan penyebab timbulnya pencemaran dan atau perusakan lingkungan hidup.

Penjelasan Pasal 87 ayat (1) tersebut telah memberikan gambaran bahwa asas-asas yang berkembang dan berpengaruh dalam hukum lingkungan internasional, beberapa diantaranya telah diadopsi dalam Undang-undang Lingkungan Indonesia agar tercipta kemajuan ekonomi dan pembangunan tanpa mengabaikan lingkungan. Mengenai ganti rugi yang harus dibayarkan pencemar terhadap dampak yang timbul akibat pencemaran, Peraturan Menteri Lingkungan Hidup Nomor 13 Tahun 2011 tentang Ganti Rugi Akibat Pencemaran dan/atau Perusakan Lingkungan memberikan pedoman bagi penyelesaian sengketa lingkungan baik melalui pengadilan maupun di luar pengadilan. Peraturan menteri tersebut mengintrodusir komponen-komponen yang harus dimasukan dalam penghitungan ganti rugi baik individu maupun lingkungan.

Oleh karena itu, bagi pelaku usaha yang memiliki izin, manakala aktivitas bisnis tersebut menimbulkan kerusakan lingkungan karena telah melampaui atau melanggar baku mutu kerusakan lingkungan yang ditetapkan, maka kepada perusahaan tersebut harus dikenakan sanksi berupa membayar sejumlah uang (uang paksa/dwangsom), bukan denda administratif, yang ditetapkan oleh pemerintah (daerah), tanpa harus melalui proses persidangan (gugatan di pengadilan). Sanksi yang diberikan bersifat langsung, setelah dilakukan penghitungan oleh tim ahli (akuntan) tentang besarnya uang yang wajib dibayar yang setara dengan kerusakan lingkungan yang ditimbulkan.

Terhadap Pelaku usaha yang tidak memiliki izin (PETI), tanpa harus mengkaji apakah telah melanggar baku mutu kerusakan atau tidak, pelaku kegiatan tambang tersebut harus dikenakan kewajiban membayar uang paksa guna merehabilitasi lingkungan yang rusak akibat dari aktivitas tambang tersebut. Selain itu, kepada pelaku juga dapat dikenakan sanksi yang lain sesuai dengan ketentuan yang berlaku.

Secara teori, instrumen ekonomi menjanjikan hasil yang baik terhadap 
penaatan hukum lingkungan. Dalam prakteknya, belum adanya peraturan pelaksana terkait instrumen ekonomi yang menyebabkan kegagapan pemerintah dalam penerapannya dan keengganan pelaku usaha untuk melaksanakannya. Dari sekian banyak bentuk instrumen ekonomi yang diatur dalam UUPPLH, hanya 4 (empat) bentuk instrumen ekonomi yang mulai dapat dilihat penerapannya di Indonesia, yaitu:

a. Pajak dan subsidi Lingkungan. Bentuk ini yang paling mudah dipahami dan diterapkan, walaupun tidak diatur secara khusus. Beberapa peraturan pemerintah dan peraturan daerah memasukkan instrumen ini sebagai bentuk insentif dan disinsentif dalam peraturan terkait. Contohnya adalah dalam peraturan mengenai pajak bumi dan bangunan, diberikan insentif pemotongan pajak bagi bangunan ramah lingkungan, juga dalam peraturan mengenai pajak kendaraan diberikan subsidi bagi kendaraan ramah lingkungan.

b. Perdagangan izin pembuangan limbah dan/atau emisi. Mekanisme ini diwujudkan dalam bentuk mekanisme REDD yang masih menghadapi berbagai kendala dalam pelaksanaannya.

c. Pembayaran jasa lingkungan. Mekanisme imbal jasa lingkungan antar pemerintah daerah telah dilakukan terutama terkait dengan pengelolaan sampah di kota-kota besar. Contohnya Pemerintah Kota Bandung memberikan imbal jasa bagi Pemerintah Kabupaten Bandung yang menyediakan Tempat Pembuangan Sampah Akhir bagi sampah Kota Bandung. Pembayaran jasa lingkungan juga mulai diinternalisasikan dalam retribusi kawasan wisata alam seperti yang dilakukan di kawasan wisata Kawah Putih, Kabupaten Bandung.

d. Label Ramah lingkungan. Sudah banyak produk-produk yang menggunakan label ramah lingkungan, tetapi hal ini belum menjadi pertimbangan utama masyarakat Indonesia dalam membeli suatu produk. Meskipun demikian, penggunaan label ini cukup menunjukkan bahwa perusahaan-perusahaan besar di Indonesia mulai menempatkan pertimbangan lingkungan sebagai poin penting dalam manajemen perusahaannya.

Dari keempat bentuk instrumen ekonomi tersebut diatas. Jasa lingkungan dan label ramah lingkungan masih diperdebatkan posisinya apakah bagian dari instrumen ekonomi atau bukan. Beberapa kalangan berpendapat bahwa instrumen ekonomi, sebagaimana teori-teori yang 
disebutkan diatas hanya terdiri atas pajak, deposit refund system, treadable permit, dan subsidi, sisanya adalah praktek ekonomi yang diberi label ramah lingkungan. Di luar perdebatan yang terjadi, dari sudut pandang penaatan hukum yang tujuannya adalah diterapkannya persyaratan lingkungan oleh para pemangku kepentingan, instrument ekonomi memiliki peran yang signifikan.

\section{Penutup}

Berdasarkan uraian diatas, dapat diketahui bahwa Prinsip Pencemar Membayar tidak memiliki pembenar menurut hukum untuk digunakan sebagai dasar pertanggungjawaban terhadap kasus-kasus pencemaran. Namun demikian, prinsip tersebut dapat dijadikan perbandingan bagi sistem hukum lingkungan dan tetap menjadi bagian penting dalam pembaharuan hukum agraria, khususnya reformasi sumber daya alam dan lingkungan. Penerapan Prinsip Pencemar Membayar tidak hanya berarti bahwa pencemar membayar biaya atau ganti rugi atas kerusakan yang ditimbulkan, tetapi juga sebagai upaya tindakan preventif demi terjaganya kelestarian lingkungan dan fungsi lingkungan.

\section{Prinsip Pencemar Membayar} dapat digunakan dalam mendukung reformasi sumber daya alam dalam pengelolaan lingkungan hidup apabila dilakukan proses normatifikasi dalam sistem hukum lingkungan di Indonesia.

\section{Bibliografi}

\section{Buku:}

Black, Henry Campbell. 1990. Black's Law Dictionary, $6^{\text {th }}$ Ed. St. Paul: West Publishing Co.

Bruggink, J.J.H. 1999 Refleksi tentang Hukum. Bandung. Citra Aditya Bakti.

Djajadiningrat, Surna T. 1997. Pengantar Ekonomi Lingkungan. Jakarta: LP3ES.

Faure, Michael and Nicole Niessen (ed). 2006. Environmental Law in Development, Lessons from the Indonesian Experience, Cheltenham: Edward Elgar Publishing Limited.

Faure, Michael and Goran Skogh. 2003. The Economic Analysis of Environmental Policy an Law, An Introduction. Massachusett: Edward Elgar Pulishing, Inc.

Hardjasoemantri, Koesnadi. 2006. Hukum Tata Lingkungan, Edisi Kedelapan, Yogyakarta: Gadjah Mada University Press.

Irham. 2007. Valuasi Ekonomi dan Pengelolaan Sumber Daya Alam dalam Kerangka Kebijakan Pembangunan Berkelanjutan, Pidato Pengukuhan Guru Besar Pada Fakultas Pertanian Universitas Gadjah Mada, Yogyakarta.

Kemp, David D. 1998. The Environment Dictionary. London: Routledge.

Marzuki, Peter Mahmud. 2010. Penelitian Hukum. Jakarta: Kencana.

Mertokusumo, Sudikno. 2005. Mengenal Hukum: Suatu Pengantar. Yogyakarta: Liberty. 
Plater, Zygmunt J.B., Robert $H$. Abrams, Williams Goldfarb. 1992, Environmental Law and Policy: Nature, Law, and Society. St. Paul: West Publishing Co.

Rangkuti, Sundari. 2000. Hukum Lingkungan dan Kebijaksanaan Lingkungan Nasional. Surabaya: Airlangga University Press.

Sands, Philip. 2003. Principles of International Environmental Law, Second Edition. Cambridge: Cambridge University Press.

Schlosberg, David. 2007. Defining Environmental Justice, Theories, Movements, and Nature: New York:.Oxford University Press.

Seerden, Rene J.G.H., Michiel A, Heldeweg, Kurt R. Deketelaere (ed). 2002, Public Environmental Law in the European Union and the United States, A Comparative Analysis.The Hague: Kluwer Law International.

Silalahi, Daud M.1996. Hukum Lingkungan, Dalam Sistem Penegakan Hukum Lingkungan Indonesia. Bandung: Alumni.

Suparmoko. 2006. Ekonomi Sumber Daya Alam dan Lingkungan (Suatu Pendekatan Teoritis), Edisi Ketiga. Yogyakarta. BPFE.

Supriharyono. 2007. Konservasi Ekosistem Sumber Daya Hayati, di Wilayah Pesisir dan Laut Tropis. Yogyakarta: Pustaka Pelajar.

Triatmodjo, Marsudi. 2001, Pengembangan Pengaturan Hukum dan Kelembagaan Pencemaran Laut oleh Sumber dari Darat di Kawasan Asia Tenggara, Disertasi pada Universitas Gadjah Mada, Yogyakarta.

\section{Artikel Jurnal:}

Triatmodjo, Marsudi, 1998. "Peran dan Fungsi Soft Law dalam Perkembangan Hukum Internasional tentang HAM dan Lingkungan Hidup". Jurnal Mimbar Hukum. 31 (VIII). 43.

Wibisana, Andry G. 2017. "Keadilan dalam Satu (Intra) Generasi: Sebuah Pengantar Berdasarkan Taksonomi Keadilan Lingkungan". Jurnal Mimbar Hukum. 29 (2). 292-307.

\section{Peraturan Hukum:}

Undang-Undang Nomor 5 Tahun 1960 tentang Pokok Agraria.

Undang-Undang Nomor 1 Tahun 1961 tentang Penanaman Modal Asing.

Undang-Undang Nomor 11 Tahun 1967 tentang Pertambangan.

Undang-Undang Nomor 23 Tahun 1997 tentang Pengelolaan Lingkungan Hidup.

Undang-Undang Nomor 32 Tahun 2009 tentang Perlindungan dan Pengelolaan Lingkungan Hidup.

Peraturan Menteri Lingkungan Hidup Nomor 13 Tahun 2011 tentang Ganti Rugi Akibat Pencemaran dan/ atau Perusakan Lingkungan. United Nations Environmental
Programme $(U N E P) .1992$.

United Nations Economic Commission for Europe (UNECE). 1992.

European Communities Civil and Comercial Matters. 1993.

$\begin{array}{cc}\text { London Protocol, } & \text { (International } \\ \text { Maritime } & \text { Organization), } \\ \text { 1972/1996. } & \end{array}$

The Rio Declaration. 1992. 


\section{Internet:}

Glazyrina, Irina, Vesiliy Glazyrin, Sergey Vinnichenko, 2005. "The Prinsip Pencemar Membayar and Potential Conflicts in Society", tersedia di http:/www.sciencedirect.com//poll uter_pays_principle_analysis.pdf. (diakses 1 November 2016). 